A Comparison of Precise Fertilization Prescription Rates to a Conventional Approach Based on the Open Source GIS Software

Modeliranje karte za preciznu gnojidbu korištenjem GIS programa otvorenoga koda

Jurišić, M., Radočaj, D., Plaščak, I., Rapčan, I.

Poljoprivreda/Agriculture

ISSN: 1848-8080 (Online)

ISSN: 1330-7142 (Print)

https://doi.org/10.18047/poljo.27.1.7

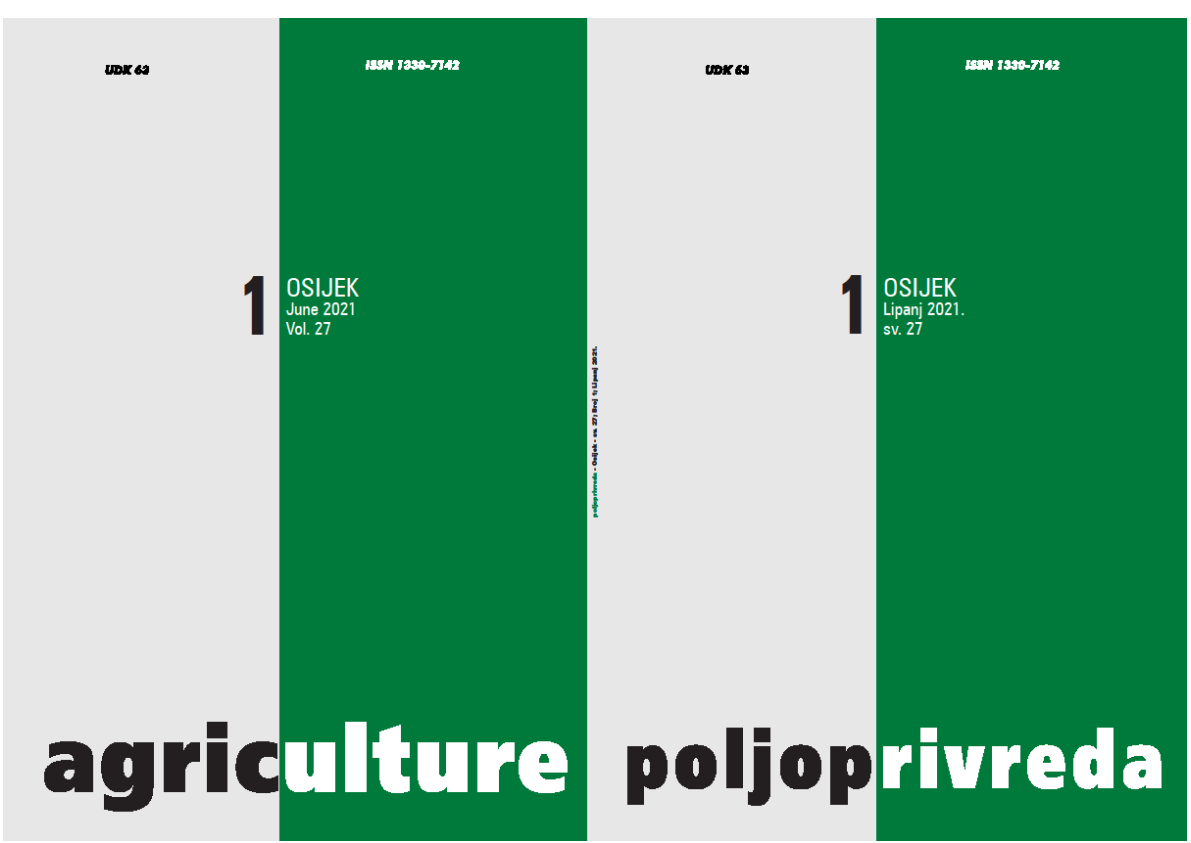

Fakultet agrobiotehničkih znanosti Osijek, Poljoprivredni institut Osijek

Faculty of Agrobiotechnical Sciences Osijek, Agricultural Institute Osijek 


\title{
A COMPARISON OF PRECISE FERTILIZATION PRESCRIPTION RATES TO A CONVENTIONAL APPROACH BASED ON THE OPEN SOURCE GIS SOFTWARE
}

Jurišić, M., Radočaj, D., Plaščak, I., Rapčan, I.

Preliminary communication

Prethodno priopćenje

\begin{abstract}
SUMMARY
Fertilization is one of the most important components of precision agriculture, ensuring high and stable crop yields. The process of spatial interpolation of soil sample data is recognized as a reliable method of determining the prescription rates for precise fertilization. However, the application of a free open-source geographic information system (GIS) software was often overlooked in the process. In this study, a method of precise fertilization prescription map creation was developed using an open-source GIS software to enable a wider and cheaper availability of its application. The study area covered three independent locations in Osijek-Baranja County. A method was developed for the fertilization of sugar beet with phosphorous pentoxide, but its application is universal with regard to the crop type. An ordinary kriging was determined as an optimal interpolation method for spatial interpolation, with the mean RMSE of 1.8754 and $R^{2}$ of 0.6955. By comparing the precision fertilization prescription rates to a conventional approach, the differences of $4.1 \mathrm{~kg} \mathrm{ha}^{-1}$ for Location 1, $15.8 \mathrm{~kg} \mathrm{ha}^{-1}$ for Location 2, and $11.2 \mathrm{~kg}$ $\mathrm{ha}^{-1}$ for Location 3 were observed. These values indicate a general deficit in soil phosphorous pentoxide, and precise fertilization could ensure its optimal content in the future sowing seasons.
\end{abstract}

Keywords: precision agriculture, spatial interpolation, kriging, SAGA GIS, geostatistics

\section{INTRODUCTION}

Precision agriculture is based on the newly developed computerized machine systems of programmed exploitation potential, using a smaller number of highreliability machines and high technological aids (Zhang and Kovacs, 2012). The application of agronomical inputs is based on a variable rate technology, allowing for the application of a necessary amount on every part of an agricultural parcel (Seelan et al., 2003). Contrary to a conventional approach based on a homogenous application of agronomical inputs over an entire agricultural area, this results in the balanced and optimal conditions in the field subsequent to the performance of agrotechnical operations. Even though precision agriculture requires a considerable investment at the beginning of its implementation, it allows for the long-term benefits with regard to the financial gains to the farmer (Tozer, 2009). It is also beneficial to environment protec- tion due to a generally lower amount of pesticides and mineral fertilizers applied, which are one of the primary sources of heavy metals and toxic organic compounds in the agricultural land in Croatia (Radočaj et al., 2020a). Fertilization in precision agriculture is one of the important factors in agricultural production, as quality fertilization is a requirement for stable crop yields. The fertilization prescription maps should therefore be based on the physiochemical soil analysis data, and the calculation of a required amount must take profitability, specific plant species needs, and soil fertility potential into account. Most of the newer agricultural machinery contains the built-in precision farming systems, allowing for an easy integration of prescription maps create in the GIS envi-

Prof. Dr. Mladen Jurišić, M. Sc. Dorijan Radočaj (dradocaj@fazos. hr), Assoc. Prof. Ivan Plaščak, Prof. Dr. Irena Rapčan - Josip Juraj Strossmayer University of Osijek, Faculty of Agrobiotechnical Sciences Osijek, Vladimira Preloga 1, 31000 Osijek, Croatia 
ronment in their controllers. This fact greatly facilitates the implementation of precision agriculture in practice, even for the smaller farms and companies. Spatial interpolation is an established procedure for the development of prescription maps in precision agriculture, enabling the prediction of a soil nutrient status using a limited soil sample number (Reyes et al., 2015). Spatial interpolation methods imply two subsets, i.e., the geostatistical and deterministic methods, which generally differ by their spatial prediction principle (Robinson and Metternicht, 2006). Geostatistical methods perform a prediction based on the quantification of spatial autocorrelation and fitting of an optimal mathematical model, selected according to the spatial input value properties. Deterministic methods utilize the simpler and universal mathematical prediction functions, most frequently with a limited number of modifiable interpolation parameters. Both groups of interpolation methods are highly applicable for a prediction of soil parameters within an agricultural field, as their performance depends on the quantity and value distribution of input soil sample data. Several free exemplars of the open-source geographic information system (GIS) software have been developed in the past decades, allowing for a global availability concerning the spatial interpolation of soil properties and the creation of prescription maps (Conrad et al., 2015). These functionalities are completely free and could reduce the cost of precise fertilization by avoiding the purchase of expensive commercial GIS and farming software.

This study's hypothesis was that a precise fertilization approach would produce a variable rate prescription considering the present soil heterogeneity, causing differences in prescription rates if compared to a conventional fertilization approach. Therefore, this study aimed to propose and evaluate a method for the creation of a prescription map for precise fertilization applying an optimal interpolation method. This was performed while utilizing a free GIS open-source software exclusively, as an alternative to the expensive commercial programs. The model was designed for a universal application regarding the crop type. It was evaluated for a precise sugar beet fertilization with phosphorous pentoxide $\left(\mathrm{P}_{2} \mathrm{O}_{5}\right)$, which represents a typical situation for the implementation of precise fertilization.

\section{MATERIAL AND METHODS}

In recent studies, the soil properties and an overall land suitability for the cultivation of various crop types in Osijek-Baranja County have demonstrated a moderate to high variability (Šiljeg et al., 2020; Radočaj et al., 2021). These observations have indicated a possibility of better agricultural land management both on a macro- and on a microlevel. Osijek-Baranja County is a historically important agricultural part of Croatia, covering approximately $14 \%$ of the country's total cultivated agricultural area, based on the most recent official data (Croatian Bureau of Statistics, 2018). The study area consisted of three subsets in Osijek-Baranja County, created by grouping the neighboring agricultural parcels, each of them forming a location with the distinctive statistical properties (Table 1). These subsets formed the study area within Osijek-Baranja County: Location $1\left(45^{\circ} 32^{\prime} \mathrm{N}, 18^{\circ} 45^{\prime} \mathrm{E}\right)$, Location $2\left(45^{\circ} 52^{\prime} \mathrm{N}, 18^{\circ} 43^{\prime} \mathrm{E}\right)$, and Location $3\left(45^{\circ} 45^{\prime}\right.$ $\mathrm{N}, 17^{\circ} 58$, E) (Figure 1). The soil samples having random sampling locations were obtained from Osijek-Baranja County's Department for Agriculture and Economy database. The survey area and soil sample characteristics are illustrated using descriptive statistics in Table 1. Location 1 covered the largest area, Location 2 had the lowest mean $\mathrm{P}_{2} \mathrm{O}_{5}$ value, while Location 3 had the highest. The sampling density in all three areas was approximately equal, averaging 4.24 samples per hectare. The coefficients of variation in all areas indicate a moderate variability in the sample values.

Table 1. Descriptive statistics of input soil samples

Tablica 1. Deskriptivna statistika ulaznih vrijednosti uzoraka tla

\begin{tabular}{|c|c|c|c|}
\hline $\begin{array}{l}\text { Property } \\
\text { Svojstvo }\end{array}$ & $\begin{array}{l}\text { Location } 1 \\
\text { Lokacija } 1\end{array}$ & $\begin{array}{l}\text { Location } 2 \\
\text { Lokacija } 2\end{array}$ & $\begin{array}{l}\text { Location } 3 \\
\text { Lokacija } 3\end{array}$ \\
\hline $\begin{array}{l}\text { Sample count } \\
\text { Broj uzoraka }\end{array}$ & 198 & 51 & 47 \\
\hline $\begin{array}{l}\text { Location area } \\
\text { Površina područja }\end{array}$ & 816 ha & 206 ha & 214 ha \\
\hline $\begin{array}{l}\text { Average area per sample } \\
\text { Prosječna površina po uzorku }\end{array}$ & $4.12 \mathrm{ha}$ & 4.04 ha & 4.55 ha \\
\hline 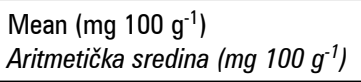 & 22.3 & 11.4 & 24.8 \\
\hline 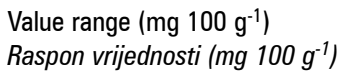 & 34.6 & 24.8 & 39.6 \\
\hline $\begin{array}{l}\text { Coefficient of variation } \\
\text { Koeficijent varijacije }\end{array}$ & $41.1 \%$ & $46.9 \%$ & $42.1 \%$ \\
\hline
\end{tabular}




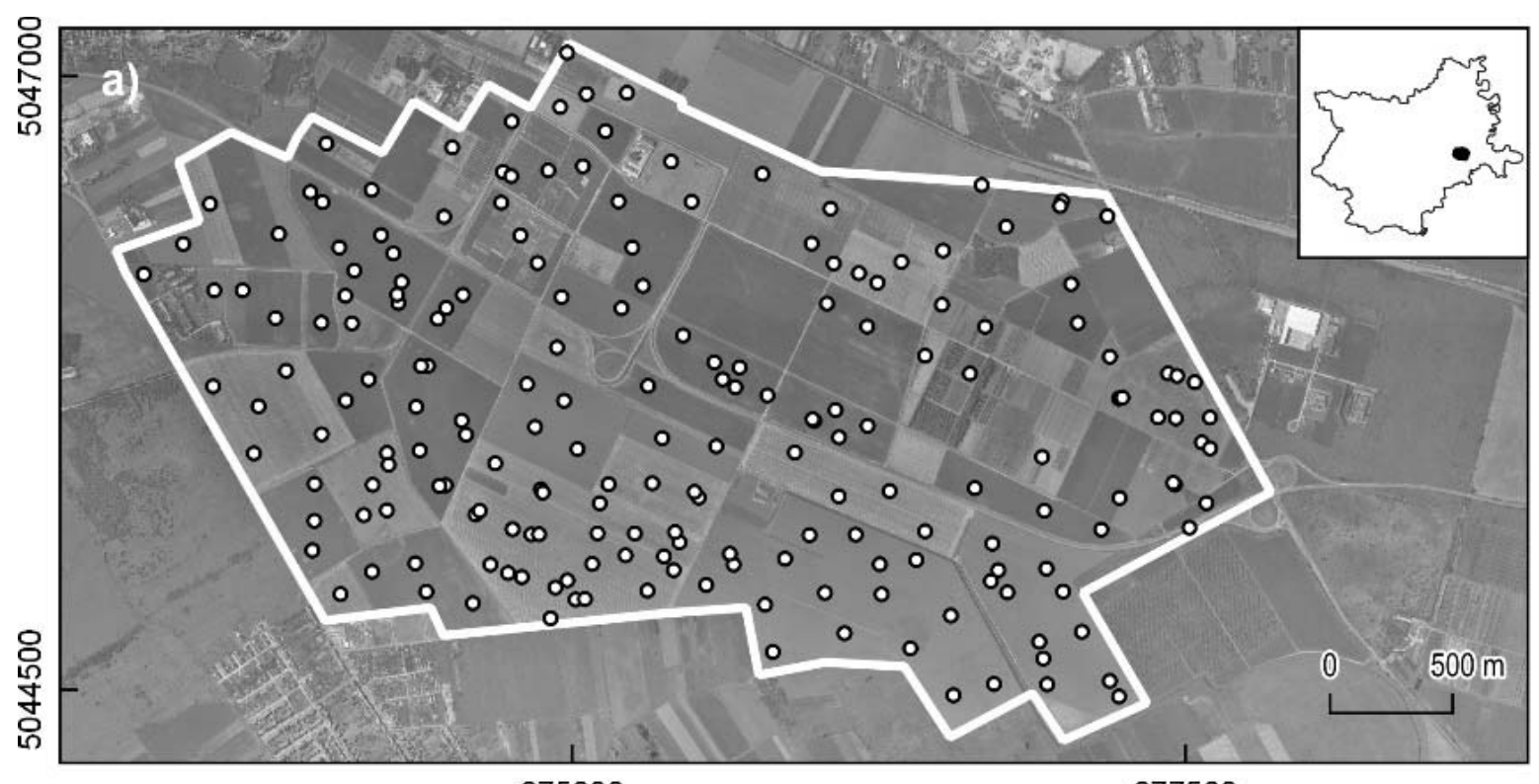

675000

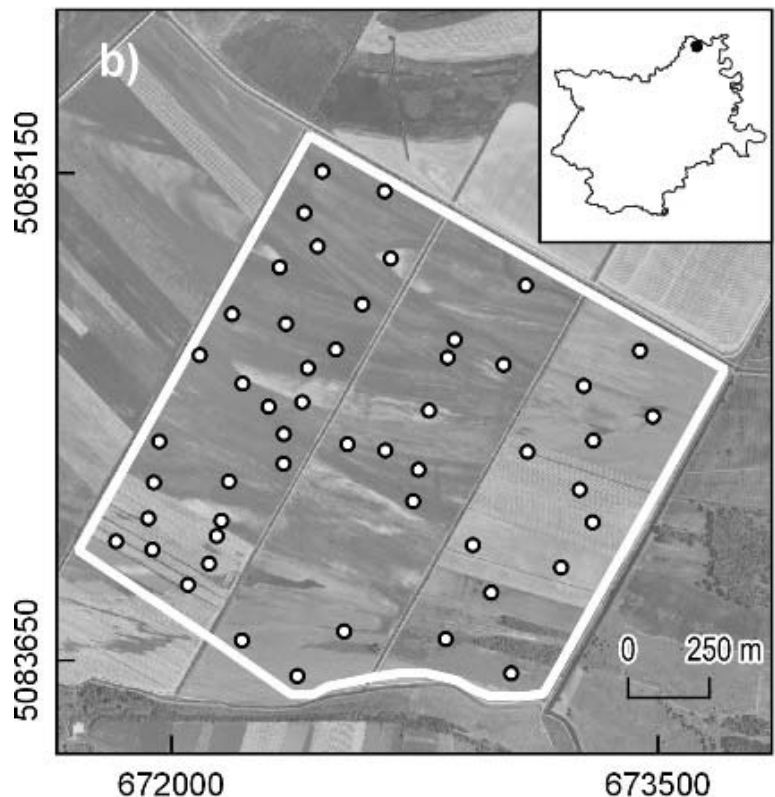

- Soil sampling locations

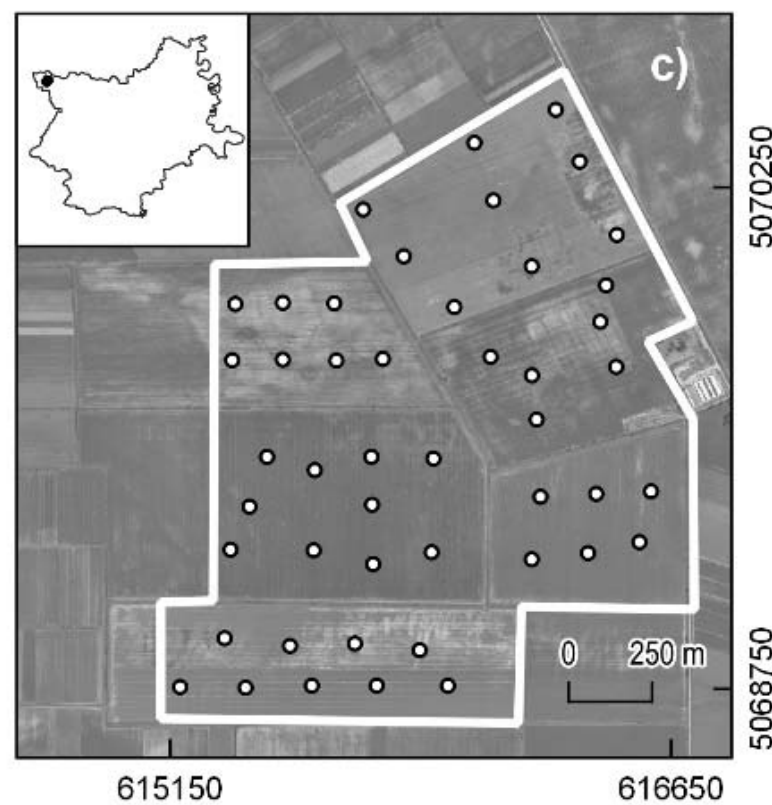

Projection: HTRS96/TM (EPSG: 3765)

Figure 1. Study area with three subsets: a) Location 1, b) Location 2, and c) Location 3

Slika 1. Područje istraživanja s trima podskupinama: a) lokacija 1, b) lokacija 2, c) lokacija 3

The evaluated spatial interpolation methods consisted of a geostatistical ordinary kriging method and two deterministic methods, i.e., of an inverse distance weighted and of an angular distance weighted. These methods produced a high interpolation accuracy and are detailly explained in the similar studies (Robinson and Metternicht, 2006). A determination of interpolation parameters was performed based on the examination of normal distribution and input data stationarity. These values are also the basic prerequisites for kriging interpolation (Jurišić et al., 2020). In this study, the examination of normal input value distribution was performed using the Shapiro-Wilk normality test in $R$ v4.0.3, RStudio v1.3. The evaluation of stationarity as a measure of local variability between the adjacent samples was performed by an interpretation of Thiessen polygon properties (Radočaj et al., 2021). The Thiessen polygons contained all points geometrically closest to a particular input soil sample. A weight coefficient modeling within an ordinary kriging was performed using a semivariogram, calculated as a distance function of all sample pairs. A mathematical model which has produced the 
best semivariogram fitting according to the highest coefficient of determination $\left(R^{2}\right)$ was selected for interpolation. The linear, Gaussian, spherical and exponential mathematical models were evaluated in the process. A logarithmic transformation was performed as a preprocess to an ordinary kriging in cases of a skewed distribution of input sample data. The number of lags during an ordinary kriging interpolation was 22 , each covering a 118-meter distance. An inverse distance weighted and an angular distance weighted were performed using an inverse-distance-to-a-power weighting function, with a weighting power of 2 . A cross-validation using the leave-one-out procedure was performed for the sake of an accuracy assessment of interpolation results pertaining to all evaluated spatial interpolation methods. A rootmean-square-error (RMSE) and $R^{2}$ were selected for an interpolation accuracy assessment, with the lower $R M S E$ and higher $R^{2}$ values indicating a higher interpolation accuracy. A spatial resolution of interpolation results was set to $50 \mathrm{~m}$, which were georeferenced in the Croatian Terrestrial Reference System (HTRS96/TM). All spatial calculations were performed in a GIS environment using an open-source SAGA GIS v7.4.0 software (Conrad et al., 2015). An interpolated data visualization and the export to the ESRI Shapefile vector format were performed using an open-source $Q G / S$ V3.10 software.

A prescription map for precise fertilization of $\mathrm{P}_{2} \mathrm{O}_{5}$ for sugar beet was created according to the existing instructions for sugar beet cultivation in the research area proposed by Jurišić (2008) (Table 2). Prescription rates were calculated as a difference between a necessary $\mathrm{P}_{2} \mathrm{O}_{5}$ soil content and its current soil quantity, determined by spatial interpolation. These values were grouped using the stepwise classification to match the defined $\mathrm{P}_{2} \mathrm{O}_{5}$ presence classes. This procedure meets a requirement of forming the relatively homogenous zones in precision agriculture (Seelan et al., 2003), as six zones were utilized in the study. Prescription rates for a conventional fertilization were calculated as a difference between the same necessary $\mathrm{P}_{2} \mathrm{O}_{5}$ soil content as in the precise fertilization approach and the average of all input soil sample values per location. This resulted in a single value per location, designated for a homogenous fertilizer application. The differences in the prescribed fertilization rates per location were determined individually, calculated as a difference between the total prescribed $\mathrm{P}_{2} \mathrm{O}_{5}$ rates in precise fertilization (Total ${ }_{\text {prec }}$ ) and a conventional approach (Total ${ }_{\text {conv }}$ ).

Table 2. Recommendation of $\mathrm{P}_{2} \mathrm{O}_{5}$ fertilization for sugar beet according to the present $\mathrm{P}_{2} \mathrm{O}_{5}$ soil content (Jurišić, 2008)

Tablica 2. Preporuka za aplikaciju $P_{2} \mathrm{O}_{5}$ za šećernu repu u odnosu na postojeću sadržaj $P_{2} \mathrm{O}_{5}$ u tlu (Jurišić, 2008.)

\begin{tabular}{|l|c|c|}
\hline $\begin{array}{l}\mathrm{P}_{2} \mathrm{O}_{5} \text { presence classes } \\
\text { Klase prisutnosti } \mathrm{P}_{2} \mathrm{O}_{5}\end{array}$ & $\begin{array}{c}\mathrm{P}_{2} \mathrm{O}_{5} \text { soil content }\left(\mathrm{mg} \mathrm{100} \mathrm{g}^{-1}\right) \\
\text { Sadržaj } \mathrm{P}_{2} \mathrm{O}_{5} \text { u tlu }\left(\mathrm{mg} \mathrm{l00} \mathrm{g}^{-1}\right)\end{array}$ & $\begin{array}{c}\text { Necessary } \mathrm{P}_{2} \mathrm{O}_{5} \text { fertilization }(\mathrm{kg} \mathrm{ha} \\
\text { Potrebna količina } P_{2} \mathrm{O}_{5}\left(\mathrm{~kg} \mathrm{ha}^{-1}\right)\end{array}$ \\
\hline O (very low / vrlo nisko) & $<5$ & 240 \\
\hline A (low / nisko) & $6-10$ & 180 \\
\hline B (moderate / umjereno) & $11-17$ & 140 \\
\hline C (high / visoko) & $18-25$ & 90 \\
\hline D (very high / vrlo visoko) & $26-35$ & 60 \\
\hline E (extremely high /ekstremno visoko) & $36>$ & 0 \\
\hline
\end{tabular}

\section{RESULTS AND DISCUSSION}

Based on the Shapiro-Wilk test, it was determined that the $\mathrm{P}_{2} \mathrm{O}_{5}$ samples for all locations do not possess a normal distribution (Table 3). Since the examined samples do not meet a normal distribution condition, a logarithmic transformation was performed as a pre-process to an ordinary kriging. The Thiessen polygons indicated moderate stationarity at Location 1, a high stationarity at Location 2, and a moderately high stationarity 3 was observed, with the exception of a high $\mathrm{P}_{2} \mathrm{O}_{5}$ concentration, in its eastern part (Fig. 2). Using the same normal distribution and stationarity tests, Hasan et al. (2014) found that the adjustment of kriging parameters, depending on the tests performed in this study, allowed for an increase in interpolation accuracy. The Thiessen polygons might cause a bias in stationarity evaluation, as they primarily depend on an observer's visual interpretation (Radočaj et al., 2021).

Table 3. Shapiro-Wilk normality test results Tablica 3. Rezultati Shapiro-Wilkova testa normalne razdiobe

\begin{tabular}{|l|c|c|}
\hline \multirow{2}{*}{$\begin{array}{l}\text { Location } \\
\text { Lokacija }\end{array}$} & \multicolumn{2}{|c|}{$\begin{array}{c}\text { Shapiro-Wilk test results } \\
\text { Rezultati Shapiro-Wilkova testa }\end{array}$} \\
\cline { 2 - 3 } & $\mathrm{W}$ & $\mathrm{P}$ \\
\hline 1 & 0.9395 & $<0.0001$ \\
\hline 2 & 0.8974 & 0.0004 \\
\hline 3 & 0.8813 & 0.0002 \\
\hline
\end{tabular}


a)

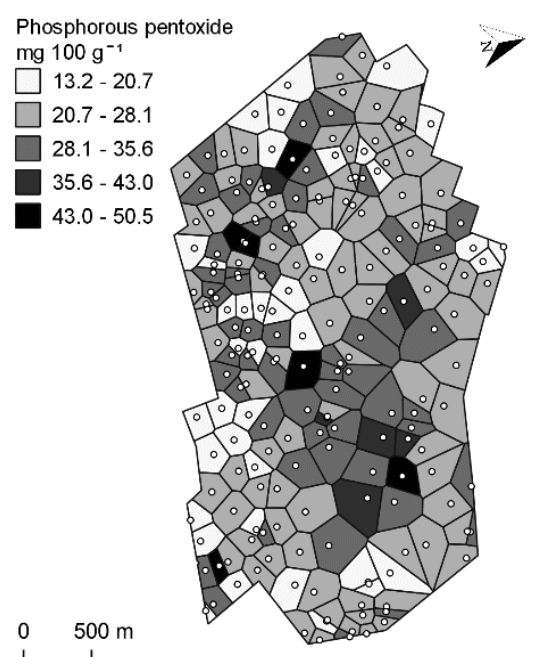

b)

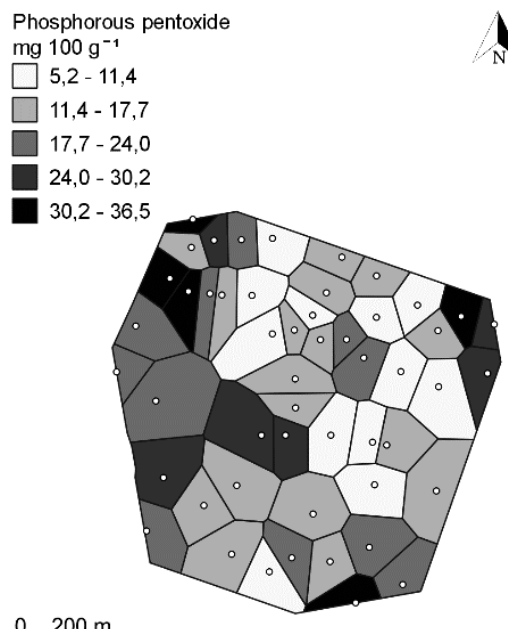

c)

Figure 2. The Thiessen polygons for: a) Location 1, b) Location 2, and c) Location 3

Slika 2. Thiessenovi poligoni za: a) lokaciju 1, b) lokaciju 2 i c) lokaciju 3

A spherical model was selected as a mathematical interpolation model due to the highest level of semivariogram correlation. An Ordinary kriging produced the highest $R M S E$ and $R^{2}$ values for all locations and was therefore determined as the most accurate interpolation method for these input samples (Table 4). It produced a mean $R M S E$ of 1.8754 and an $R^{2}$ of 0.6955 , which were influenced by the slightly lower interpolation accuracy values on Location 2. An angular distance weighted produced the second-highest interpolation accuracy for all study locations, followed by an inverse distance weighted. Both deterministic methods produced much better results on Location 1 when compared to the other two locations, which were mutually distinctive, primarily regarding a soil sample count. An ordinary kriging outperformed the deterministic interpolation methods in the similar studies as well (Dai et al., 2014), but the deterministic methods are commonly a more suitable option in cases of a low input data density, normality, or stationarity (Radočaj et al., 2020b).

Table 4. Interpolation accuracy of $\mathbf{P}_{\mathbf{2}} \mathbf{O}_{\mathbf{5}}$ per a tested interpolation method

Tablica 4. Točnost interpolacije $\mathrm{P}_{2} \mathrm{O}_{5}$ za ispitane metode interpolacije

\begin{tabular}{|l|c|c|c|c|c|c|}
\hline \multirow{2}{*}{$\begin{array}{l}\text { Location } \\
\text { Lokacija }\end{array}$} & \multicolumn{2}{|c|}{$\begin{array}{c}\text { Ordinary kriging } \\
\text { Obični kriging }\end{array}$} & \multicolumn{2}{c|}{$\begin{array}{c}\text { Inverse distance weighted } \\
\text { Metoda inverzne udaljenosti }\end{array}$} & \multicolumn{2}{c|}{$\begin{array}{c}\text { Angular distance weighted } \\
\text { Metoda kutne udaljenosti }\end{array}$} \\
\cline { 2 - 7 } & $R M S E$ & $R^{2}$ & $R M S E$ & $R^{2}$ & $R M S E$ & $R^{2}$ \\
\hline 1 & 1.6334 & 0.7332 & 2.4180 & 0.6933 & 2.4205 & 0.7056 \\
\hline 2 & 2.0537 & 0.6307 & 2.1082 & 0.3997 & 2.1068 & 0.4448 \\
\hline 3 & 1.9391 & 0.7227 & 2.6268 & 0.5701 & 2.6285 & 0.5995 \\
\hline
\end{tabular}

The highest $\mathrm{P}_{2} \mathrm{O}_{5}$ values on Location 1 were identified in the central and northern part, peaking at $30.8 \mathrm{mg}$ $100 \mathrm{~g}^{-1}$, while these values decreased toward the borders at the southwest (Fig. 3). Location 2 had the lowest $\mathrm{P}_{2} \mathrm{O}_{5}$ values compared to the other locations, primarily due to the low values at the central part. On Location 3 , the relatively high $\mathrm{P}_{2} \mathrm{O}_{5}$ values were observed in the entire area, with minor exceptions in the eastern borderline part. Standard deviations of the interpolated $\mathrm{P}_{2} \mathrm{O}_{5}$ values in all three cases indicate that the most accurate interpolated area is the one near the samples, while this accuracy decreases in proportion to a distance from the samples. Therefore, the highest standard deviations were observed at the borders of each location. 
a)

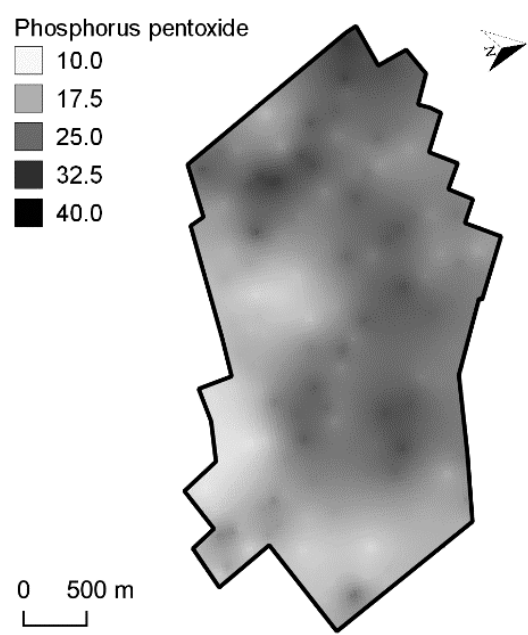

b)

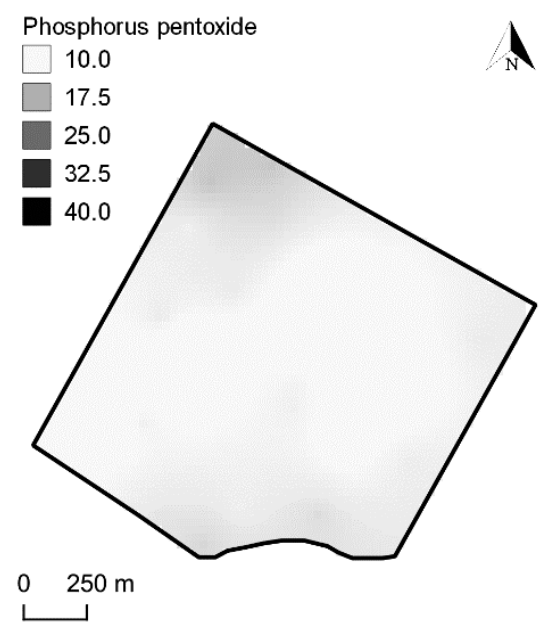

c)

Figure 3. Interpolation result of an ordinary kriging for: a) Location 1, b) Location 2, and c) Location 3

Slika 3. Rezultat interpolacije primjenom običnoga kriginga za: a) lokaciju 1, b) lokaciju 2 i c) lokaciju 3

The mean $\mathrm{P}_{2} \mathrm{O}_{5}$ values of all samples per location were applied for the calculation of $\mathrm{P}_{2} \mathrm{O}_{5}$ recommendations concerning conventional fertilization. Conventional fertilization's prescription rates amounted to $90 \mathrm{~kg} \mathrm{ha}^{-1}$ for Location 1, $140 \mathrm{~kg} \mathrm{ha}^{-1}$ for Location 2, and $90 \mathrm{~kg} \mathrm{ha}^{-1}$ for Location 3 (Table 5). The difference in prescription rates for a precise and conventional fertilization amounted to $4.1 \mathrm{~kg} \mathrm{ha}^{-1}$ for Location 1, 15.8 $\mathrm{kg} \mathrm{ha}^{-1}$ for Location 2, and $11.2 \mathrm{~kg} \mathrm{ha}^{-1}$ for Location 3. The larger differences were observed proportionally for a higher variability of the existent soil $\mathrm{P}_{2} \mathrm{O}_{5}$ values. Contrary to a common situation of a lesser quantity of necessary fertilizer in a precise fertilization approach (Tozer, 2009), the prescription rates for the Locations
1 and 2 exceeded those of a conventional approach. A larger amount of fertilizer required on these locations is present in the areas with the very low or with the extremely low existing $\mathrm{P}_{2} \mathrm{O}_{5}$ values. This situation is expected to occur in cases of an existent soilborne $\mathrm{P}_{2} \mathrm{O}_{5}$ deficit, as a larger fertilizer quantity sets soil $\mathrm{P}_{2} \mathrm{O}_{5}$ to an optimal level for sugar beet cultivation, regardless of the amount of fertilizer applied, if compared to a conventional fertilization. By applying a larger amount of fertilizer within a precise fertilization system in case of a seasonal soilborne nutrient deficiency, the better conditions are being created for a crop growth and for the long-term fertilizer savings in the future sowing seasons (Zhang and Kovacs, 2012).

Table 5. Recommendation of $\mathbf{P}_{\mathbf{2}} \mathbf{O}_{\mathbf{5}}$ fertilization for sugar beet per study location Tablica 5. Preporuka za aplikaciju $\mathrm{P}_{2} \mathrm{O}_{5}$ za šećernu repu po lokaciji istraživanja

\begin{tabular}{|c|c|c|c|c|c|c|c|c|}
\hline \multirow{2}{*}{$\begin{array}{l}\text { Location } \\
\text { Lokacija }\end{array}$} & \multicolumn{5}{|c|}{$\begin{array}{l}\text { Precise fertilization } \mathrm{P}_{2} \mathrm{O}_{5} \text { rates (ha) } \\
\text { Količina aplikacije } \mathrm{P}_{2} \mathrm{O}_{5} \text { (ha) }\end{array}$} & \multirow{2}{*}{ Total $_{\text {prec }}(\mathrm{kg})$} & \multirow{2}{*}{ Total $_{\text {conv }}(\mathrm{kg})$} & \multirow{2}{*}{$\begin{array}{c}\text { Difference }(\mathrm{kg}) \\
\text { Razlika }(\mathrm{kg})\end{array}$} \\
\hline & $\begin{array}{c}0 \\
\mathrm{~kg} \mathrm{ha}^{-1}\end{array}$ & $\begin{array}{c}60 \\
\mathrm{~kg} \mathrm{ha}^{-1}\end{array}$ & $\begin{array}{c}90 \\
\mathrm{~kg} \mathrm{ha}^{-1}\end{array}$ & $\begin{array}{c}140 \\
\mathrm{~kg} \mathrm{ha}^{-1}\end{array}$ & $\begin{array}{c}180 \\
\mathrm{~kg} \mathrm{ha}^{-1}\end{array}$ & & & \\
\hline 1 & / & 154.0 & 503.0 & 158.6 & I & 76,714 & 73,404 & 3,310 \\
\hline 2 & / & I & / & 124.6 & 81.2 & 32,060 & 28,812 & 3,248 \\
\hline 3 & 16.7 & 53.8 & 129.2 & 14.4 & I & 16,872 & 19,269 & $-2,397$ \\
\hline
\end{tabular}

According to the modeled fertilization maps, the need for $\mathrm{P}_{2} \mathrm{O}_{5}$ is maximal and uniform throughout Location 2, with only two zones for precise fertilization (Fig. 4). The precise fertilization prescription rates at Locations 1 and 3 contain large variations, with four zones nearly equally distributed in them. The creation of management zones in precise fertilization could be upgraded by adopting the unsupervised classification. It was successfully applied for the delineation of soil $\mathrm{C} / \mathrm{N}$ management zones in the study area by Radočaj et al. (2021) and could severely reduce a possibility of operator's subjective error in the formation of prescription rates zones. 
a)

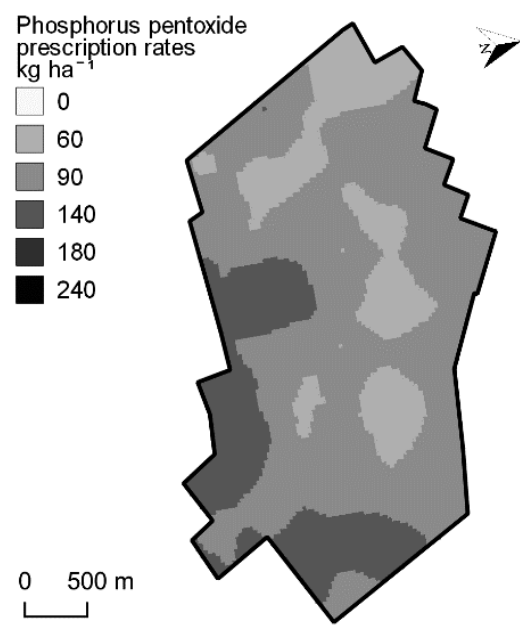

b)

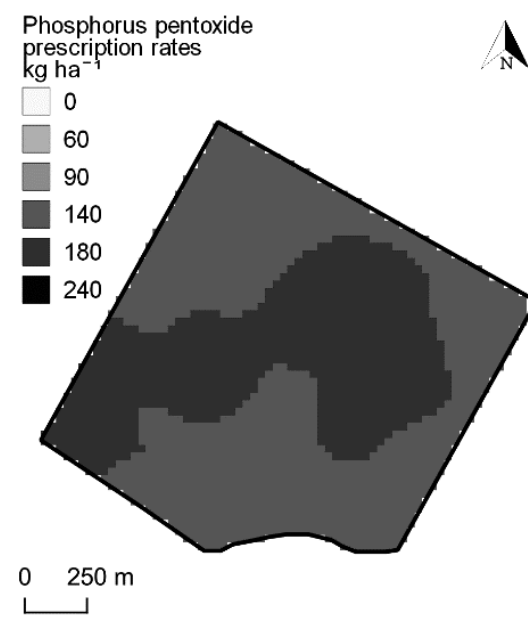

c)

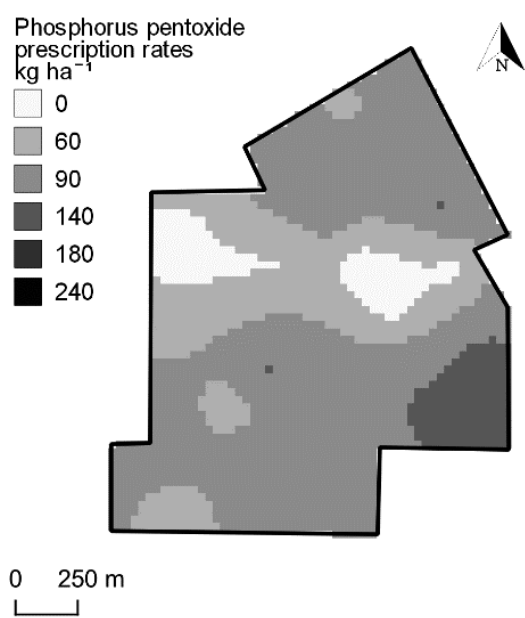

Figure 4. Recommended prescription rates of $\mathrm{P}_{2} \mathbf{O}_{5}$ for a) Location 1 , b) Location 2, and c) Location 3

Slika 4. Preporučene količine aplikacije $P_{2} \mathrm{O}_{5}$ za a) lokaciju 1, b) lokaciju 2 i c) lokaciju 3

\section{CONCLUSION}

The application of the free open-source SAGA $G / S$ and $Q G I S$ software allowed for the obtainment of necessary results for the creation of prescription maps in precise fertilization. This primarily refers to the evaluation of spatial interpolation methods, which had a major impact on the final prescription rates. An ordinary kriging produced a superior interpolation accuracy on all three study locations, compared to the two deterministic interpolation methods, an inverse distance weighted and an angular distance weighted, respectively. The application of ordinary kriging for a prescription map creation also enabled the operator to control the interpolation parameters, in contrast to the commercial solutions where this procedure is often simplified or inaccessible. The proposed model resulted in the higher precise fertilization prescription rates when compared to a conventional approach on two out of three study locations. The differences in precise and conventional fertilization prescription rates of $4.1 \mathrm{~kg} \mathrm{ha}^{-1}, 15.8 \mathrm{~kg} \mathrm{ha}^{-1}$, and $11.2 \mathrm{~kg} \mathrm{ha}^{-1}$ for the Locations 1,2 , and 3, respectively, have confirmed the study hypothesis. In accordance with the principle of precise fertilization, the application of the recommended $\mathrm{P}_{2} \mathrm{O}_{5}$ values would enable an optimal amount of phosphorus for sugar beet cultivation, as opposed to a conventional fertilization, after which there would still be a significant $\mathrm{P}_{2} \mathrm{O}_{5}$ deficit in the soil. By applying the proposed amount of fertilizer with a higher nutrient deficit in the soil, a basis is created for a lesser application of fertilizer in the future sowing seasons if compared to a conventional fertilization. The developed model supports a precise fertilization regardless of the soil element or the crop type. The accessibility of creating a fertilization map in the vector ESRI Shapefile format enables the efficient connection between the GIS analysts and tractor operators in the process of precise fertilization.

\section{ACKNOWLEDGEMENTS}

This work was supported by the Faculty of Agrobiotechnical Sciences Osijek as a part of the scientific project AgroGIT - Technical and Technological Crop Production Systems, GIS, and Environment Protection.

\section{REFERENCES}

1. Conrad, O., Bechtel, B., Bock, M., Dietrich, H., Fischer, E., Gerlitz, L., Wehberg, J., Wichmann, V., \& Böhner, J. (2015). System for automated geoscientific analyses (SAGA) v. 2.1. 4. Geoscientific Model Development, 8(7), 1991-2007. https://doi.org/10.5194/gmd-8-19912015

2. Croatian Bureau of Statistics. (2018). Agriculture review by counties. https://www.dzs.hr/Hrv_Eng/ Pokazatelji/Poljoprivreda\%20-\%20pregled\%20po\%20 zupanijama.XLSX

3. Dai, F., Zhou, Q., Lv, Z., Wang, X., \& Liu, G. (2014). Spatial prediction of soil organic matter content integrating artificial neural network and ordinary kriging in Tibetan Plateau. Ecological Indicators, 45, 184-194. https://doi.org/10.1016/j.ecolind.2014.04.003

4. Jurišić, M. (2008). AgBase - Manual for plant production - I. Technology (agrotechnics) of important crop types. Josip Juraj Strossmayer University of Osijek, Faculty of Agriculture 0sijek.

5. Jurišić, M., Radočaj, D., Krčmar, S., Plaščak, I., \& Gašparović, M. (2020). Geostatistical analysis of soil C/N deficiency and its effect on agricultural land management of major crops in eastern Croatia. Agronomy, 10(12), 1996. https://doi.org/10.3390/agronomy10121996

6. Radočaj, D., Velić, N., Jurišić, M., \& Merdić, E. (2020a). The remediation of agricultural land contaminated by heavy metals. Poljoprivreda, 26(2), 30-42. https://doi. org/10.18047/poljo.26.2.4

7. Radočaj, D., Jurišić, M., Župan, R., \& Antonić, 0. (2020b). Spatial prediction of heavy metal soil contents 
in continental Croatia comparing machine learning and spatial interpolation methods. Geodetski list, 74(4), 357372.

8. Radočaj, D., Jurišić, M., \& Antonić, O. (2021). Determination of soil C: $\mathrm{N}$ suitability zones for organic farming using an unsupervised classification in eastern Croatia. Ecological Indicators, 123, 107382. https://doi. org/10.1016/j.ecolind.2021.107382

9. Reyes, J. F., Esquivel, W., Cifuentes, D., \& Ortega, R. (2015). Field testing of an automatic control system for variable rate fertilizer application. Computers and Electronics in Agriculture, 113, 260-265. https://doi. org/10.1016/j.compag.2015.03.003

10. Robinson, T. P., \& Metternicht, G. (2006). Testing the performance of spatial interpolation techniques for mapping soil properties. Computers and Electronics in Agriculture, 50(2), 97-108. https://doi.org/10.1016/j. compag.2005.07.003
11. Seelan, S. K., Laguette, S., Casady, G. M., \& Seielstad, G. A. (2003). Remote sensing applications for precision agriculture: A learning community approach. Remote Sensing of Environment, 88(1-2), 157-169. https://doi. org/10.1016/j.rse.2003.04.007

12. Šiljeg, A., Jurišić, M., Radočaj, D., \& Videković, M. (2020). Modeliranje pogodnosti poljoprivrednog zemljišta za uzgoj ječma uporabom višekriterijske GIS analize. Poljoprivreda, 26(1), 40-47. https://doi.org/10.18047/ poljo.26.1.6

13. Tozer, P. R. (2009). Uncertainty and investment in precision agriculture - is it worth the money? Agricultural Systems, 100(1-3), 80-87. https://doi.org/10.1016/j. agsy.2009.02.001

14. Zhang, C., \& Kovacs, J. M. (2012). The application of small unmanned aerial systems for precision agriculture: a review. Precision Agriculture, 13(6), 693-712. https://doi.org/10.1007/s11119-012-9274-5

\section{MODELIRANJE KARTE ZA PRECIZNU GNOJIDBU KORIŠTENJEM GIS PROGRAMA OTVORENOGA KODA}

\section{SAŽETAK}

Gnojidba je jedna od najvažnijih sastavnica precizne poljoprivrede koja osigurava visoke $i$ stabilne prinose usjeva. Proces prostorne interpolacije podataka uzorka tla prepoznat je kao pouzdana metoda određivanja stope aplikacije u preciznoj gnojidbi. Međutim, primjeni besplatnih softvera geografskoga informacijskog sustava (GIS) otvorenoga koda često nije dana dovoljna pozornost. $U$ ovome je istraživanju razvijena metoda modeliranja karte za preciznu gnojidbu korištenjem GIS softvera otvorenoga koda kako bi se omogućila šira i jeftinija dostupnost njezine primjene. Područje ispitivanja obuhvaćalo je tri neovisne lokacije u Osječko-baranjskoj županiji. Razvijena je metoda za preciznu gnojidbu šećerne repe za fosforov pentoksid, no njezina primjena je univerzalna bez obzira na vrstu usjeva. Obični kriging određen je kao optimalna metoda interpolacije, sa srednjim vrijednostima RMSE-a od 1,8754 i $R^{2}$ od 0,6955 . Usporedbom modeliranih vrijednosti precizne gnojidbe $s$ konvencionalnim pristupom uočene su razlike od 4,1 kg ha-1 za lokaciju 1, 15,8 kg ha ${ }^{-1}$ za lokaciju 2 i 11,2 kg ha-1 za lokaciju 3. Te vrijednosti ukazuju na deficit fosforova pentoksida u tlu, a precizna gnojidba mogla bi osigurati njegov optimalan sadržaj u budućim sezonama sjetve.

Ključne riječi: precizna poljoprivreda, prostorna interpolacija, kriging, SAGA GIS, geostatistika

(Received on February 22, 2021; accepted on April 13, 2021 - Primljeno 22. veljače 2021.; prihvaćeno 13. travnja 2021.) 